\title{
KARAKTERISTIK PERUSAHAAN, TATA KELOLA PERUSAHAAN DAN MANAJEMEN LABA
}

\author{
Ardiana Luthvita Sari \\ Universitas Katolik Soegijapranata
}

\begin{abstract}
This study examines the effect of audit committee expertise, audit committee meeting frequency, audit committee size, commissioner board expertise, board composition, firm size, leverage, auditor reputation, to earnings management. Earnings management is the selection of accounting policies by managers for personal purposes at the expense of shareholders' interests. This study predicts the better the audit committee skills the lower the earnings management. The more often the audit committee holds the frequency of meetings, the less profit management. The larger the audit committee size the lower the earnings management. The more the board of commissioners the lower the profit management. The more members of the board composition the lower the earnings management. The more sizes the higher the profit management. The higher the leverage the higher the profit management. The reputation of the auditor negatively affects earnings management. The results showed that: 1) There was a significant positive influence between Audit Committee Skills on earnings management. 2) Frequency Audit Committee meetings have a significant negative effect on earnings management. 3) The size of Audit Committee has a significant negative effect on earnings management. 4) The Board of Commissioners' expertise has a significant negative effect on earnings management. 5) The composition of the Board of Commissioners has a significant positive effect on earnings management. 6) Size (Size Company) have a significant effect on earnings management. 7) DER (Leverage) has no significant effect on earnings management. 8) Reputation Auditors have no significant effect on earnings management.
\end{abstract}

Keywords: Audit committee, auditor reputation, board of commissioners, firm size.

\begin{abstract}
Abstrak
Penelitian ini menguji pengaruh keahlian komite audit, frekwensi rapat komite audit, ukuran komite audit, keahlian dewan komisaris, komposisi dewan komisaris, ukuran perusahaan, leverage, reputasi auditor, terhadap manajemen laba. Manajemen laba merupakan pemilihan kebijakan akuntansi oleh manajer untuk tujuan pribadi dengan mengorbankan kepentingan pemegang saham. Penelitian ini memprediksi semakin baik keahlian komite audit semakin rendah manajemen laba. Semakin sering komite audit mengadakan frekuensi rapat maka semakin menurun manajemen laba. Semakin besar ukuran komite audit maka semakin rendah manajemen laba. Semakin ahli dewan komisaris maka semakin rendah manajemen laba. Semakin banyak anggota komposisi dewan komisaris maka semakin rendah manajemen laba. Semakin bersar ukuran maka semakin tinggi manajemen laba. Semakin tinggi leverage maka semakin tinggi manajemen laba. Reputasi auditor berpengaruh negatif terhadap manajemen laba. Hasil penelitian menunjukkan bahwa: 1) Terdapat pengaruh positif signifikan antara Keahlian Komite audit terhadap manajemen laba. 2) Frekuensi Rapat komite audit berpengaruh negatif signifikan terhadap manajemen laba. 3) Ukuran Komite Audit berpengaruh negatif signifikan terhadap manajemen laba. 4) Keahlian Dewan Komisaris berpengaruh negatif signifikan terhadap manajemen laba. 5) Komposisi Dewan Komisaris berpengaruh positif signifikan terhadap manajemen laba. 6) Ukuran Perusahaan berpengaruh signifikan terhadap manajemen laba. 7) DER (Leverage) tidak berpengaruh signifikan
\end{abstract}


terhadap manajemen laba. 8) Reputasi Auditor tidak berpengaruh signifikan terhadap manajemen laba.

\section{Kata Kunci : komite audit, reputasi auditor, dewan komisaris, ukuran perusahaan}

\section{PENDAHULUAN}

Laporan keuangan merupakan bentuk pertanggung jawaban manajemen kepada calon investor pada umumnya dan pemegang saham khususnya. Laporan keuangan memberikan informasi yang berguna kepada para pengguna umumnya untuk pembuatan keputusan. Oleh karena itu, sepatutnya laporan keuangan dapat memenuhi keperluan para pengguna terutama berkaitan dengan validitas informasi tersebut. Informasi yang diberikan seharusnya informasi yang dapat dipercaya (Nini dan Trisnawati, 2009).

Krischenheiter dan melumad (2002) dalam Carolina dan Juniarti (2005) menyatakan bahwa laba merupakan salah satu informasi potensial yang terkandung di dalam laporan keuangan dan yang sangat penting bagi pihak internal maupun eksternal perusahaan. Informasi laba merupakan komponen laporan keuangan perusahaan yang bertujuan untuk menilai kinerja manajemen, membantu mengestimasi kemampuan laba yang representatif dalam jangka panjang, meramalkan laba, menaksir risiko dalam berinvestasi atau meminjamkan dana.

Namun dalam kenyataannya banyak perusahaan yang sengaja melakukan praktik manajemen laba untuk memberikan informasi kepada masyarakat bahwa perusahaan mereka masih dalam kondisi yang baik atau sehat, sehingga masih menjaga kepercayaan masyarakat terhadap informasi laporan keuangan yang di hasilkan.

Adanya manajemen laba ini didukung oleh PSAK Nomor 1 yang menyebutkan bahwa laporan keuangan harus disusun berdasarkan dasar akrual bukan dasar kas. Selain itu, berdasarkan prinsip akuntansi yang berterima umum (Generally Accepted Acounting Principle atau GAAP) yang dikutip dari Ulfi (2006), perusahaan menggunakan akuntansi akrual (accrual accounting) yang "mencoba mencatat pengaruh finansial dari transaksi atas kejadian usaha yang dialami oleh suatu entitas yang mempunyai konsekuensi tunai bagi entitas tersebut pada satu periode dimana transaksi, kejadian, dan peristiwa tersebut terjadi bukan hanya pada saat kas diterima atau dibayarkan oleh entitas yang bersangkutan". Pada akhirnya terkadang prinsip akrual ini ini disalahgunakan manajemen untuk mengelabui pihak pemilik perusahaan.

Manajemen laba adalah salah satu kajian menarik dalam riset akuntansi. Menurut Watts dan Zimmerman,1986 dalam Pamudji dan Trihartati (2010) Manajemen laba dilakukan oleh manajemen perusahaan yang mencapai berbagai tujuan,seperti:memperoleh bonus, menghindari pelanggaran perjanjian hutang, dan menghindari political costs.

Jika pada suatu kondisi dimana pihak manajemen ternyata tidak berhasil mencapai target laba yang ditentukan, maka manajemen akan memanfaatkan fleksibiltas yang diperbolehkan oleh standar akuntansi dalam menyusun laporan keuangan untuk memodifikasi laba yang dilaporkan. Manajemen termotivasi untuk memperlihatkan kinerja yang baik dalam menghasilkan nilai atau keuntungan maksimal bagi perusahaan sehingga manajemen cenderung memilih dan menerapkan metode akuntansi yang dapat memberikan informasi laba lebih baik (Tobing et al, 2005 dalam Rahmawati, 2008).

Menurut Jati dan Sanjaya (2013) konsep manajemen laba menggunakan pendekatan teori keagenan (agency theory) yang menyatakan bahwa praktik manajemen laba dipengaruhi oleh konflik kepentingan antara manajemen (agent) dan pemilik (principal) yang timbul ketika setiap pihak berusaha untuk mencapai atau mempertahankan tingkat 
kemakmuran yang dikehendakinya. Dalam hubungan keagenan, manajer memiliki asimetri informasi terhadap pihak eksternal perusahaan, seperti kreditor dan investor. Asimetri informasi terjadi ketika manajer memiliki informasi internal perusahaan relatif lebih banyak dan mengetahui informasi tersebut relatif lebih cepat dibandingkan pihak eksternal tersebut. Dalam kondisi demikian, manajer dapat menggunakan informasi yang diketahuinya untuk memanipulasi pelaporan keuangan dalam usaha memaksimalkan kemakmurannya.

Penelitian-penelitian mengenai faktor-faktor yang mempengaruhi manajemen laba diantaranya dilakukan oleh Siregar dan Utama (2005), Widyaningdyah (2001),Utami dan Rahmawati (2008),Sefiana (2009). Tetapi pada kenyataannya penelitian tersebut menghasilkan temuan yang tidak sama. Penelitian Siregar dan Utama (2005) menggunakan sampel perusahaan yang terdaftar di BEJ periode non krisis moneter, yaitu dari tahun 1995 sampai tahun 1996 dan tahun 1999 sampai tahun 2002. Siregar dan Utama (2005) dalam penelitiannya menggunakan variabel kepemilikan keluarga, ukuran perusahaan, dan praktik corporate governance (kualitas auditor, proporsi dewan komisaris independen, dan keberadaan komite audit). Hasil penelitian tersebut menyatakan bahwa struktur kepemilikan keluarga dan ukuran perusahaan yang berpengaruh signifikan terhadap manajemen laba. Sedangkan praktik corporate governance (kualitas auditor, proporsi dewan komisaris independen, dan keberadaan komite audit) mempunyai pengaruh yang tidak signifikan terhadap manajemen laba.

\section{TINJAUAN LITERATUR DAN PERUMUSAN HIPOTESIS}

\section{Agency Theory}

Konsep agency theory menurut Anthony dan Givondarajan (1995) seperti yang ditulis Widyaningdyah (2001) adalah hubungan atau kontrak antara principal dan agent. Principal memperkerjakan agent untuk melakukan tugas untuk kepentingan principal, termasuk pendelegasian otoritas pengambilan keputusan dari principal kepada agent. Pada perusahaan yang modalnya terdiri atas saham, pemegang saham bertindak sebagai principal, dan CEO (Chief Executive Officer) sebagai agent mereka. Pemegang saham memperkerjakan CEO untuk bertindak sesuai dengan kepentingan principal.

Mengutip Jensen dan Meckling (1976), Butar Butar (2016) mengatakan bahwa pemisahan fungsi antara pemilik dan pelaksana perusahaan berpotensi menimbulkan konflik kepentingan. Masalah keagenan muncul ketika manajer mendahulukan kepentingan pribadi di atas kepentingan pemegang saham.

\section{Manajemen Laba}

Menurut Halim et al (2005) manajemen laba merupakan pemilihan kebijakan akuntansi oleh manajer dari standar akuntansi yang ada dan secara alamiah dapat memaksimumkan utilitas mereka dan atau nilai pasar perusahaan. Cara pemahaman atas manajemen laba dapat dibagi menjadi dua cara. Pertama, melihatnya sebagai perilaku oportunistik manajer untuk memaksimumkan utilitasnya dalam menghadapi kontrak kompensasi, kontrak hutang, dan political cost (Opportunistic Earnings Management). Kedua, dengan memandang manajemen laba dari perspektif efficient contracting (Efficient Earnings Management), dimana manajemen laba memberi manajer suatu fleksibilitas untuk melindungi diri mereka dan perusahaan dalam mengantisipasi kejadian-kejadian yang tak terduga untuk keuntungan pihak-pihak yang terlibat dalam kontak. 


\section{Motivasi Manajemen dalam Melakukan Manajemen Laba}

Holthausen (1990) dalam Butar Butar (2014) membagi motivasi yang mendasari manajer dalam melakukan manajemen laba ke dalam tiga perspektif: pengontrakan efisien (efficient contracting), perilaku oportunistis (opportunistic behavior), dan perspektif informasi (informational perspectives). Dalam perspektif efficient contracting manajer memilih metode akuntansi untuk meminimalkan kos keagenan. Manajemen laba oportunistis dilakukan dengan memilih metode akuntansi yang menaikkan laba agar bonus meningkat. Dalam perspektif informasi manajemen laba dilakukan dengan memilih metode akuntansi sebagai sarana pensinyalan.

Sedangkan menurut Scott (1997) dalam Muid dan Nanang (2005), terdapat berbagai motivasi mengapa perusahaan dalam hal ini adalah manajer melakukan manajemen laba yaitu:
a. Bonus Plans
b. Debt Covenant
c. Political Motivation
d. Taxation Motivation
e. Pergantian CEO
f. Initial Public Ofering (IPO)

\section{Discretionary Accrual}

Akrual yang digunakan untuk mendeteksi apakah pihak manajemen melakukan manajemen laba dalam laporan keuangannya adalah total akrual. Total akrual terdiri dari discretionary accruals (DA) dan nondiscretionary accruals (NDA). Nondiscretionary accruals merupakan komponen akrual yang terjadi seiring dengan perubahan dari aktivitas perusahaan. Selisih antara total akrual dengan nondiscretionary accruals akan menggambarkan discretionary accruals atau akrual yang dengan sengaja diterapkan manajemen untuk tujuan tertentu. Dalam hal ini discretionary accruals dapat dianggap sebagai manajemen laba (Veronica dan Bachtiar, 2003). Hal yang sama juga diungkapkan Butar Butar (2012) bahwa penelitian manajemen laba pada umumnya terfokus pada volatilitas akrual diskresioner di seputar peristiwa-peristiwa tertentu yang terjadi dalam perusahaan.

\section{Pengembangan Hipotesis \\ Keahlian Komite Audit}

Komite audit dibentuk sebagai salah satu komite khusus di perusahaan untuk mengoptimalkan fungsi pengawasan yang sebelumnya merupakan tanggung jawab penuh dari dewan komisaris. Komite audit terdiri dari sedikitnya tiga orang, diketuai oleh komisaris independen perusahaan dengan proporsi 30\% untuk terselenggaranya pengelolaan korporasi yang baik,sedangkan anggota lain nya merupakan pihak independen dimana sekurang-kurangnya satu di antaranya memiliki kemampuan di bidang akutansi atau keuangan ( Keputusan Direksi PT Bursa Efek Jakarta)

Penelitian Carcello et al (2010) menyatakan bahwa keahlian komite audit dan mekanisme corporate governance berpengaruh terhadap manajemen laba. Penelitian ini menggunakan sampel perusahaan di US. Artinya semakin baik keahlian komite audit menunjukkan proses audit yang semakin baik sehingga berpengaruh terhadap indikasi menurunnya manajemen laba.

Dengan demikian hipotesis dari penelitian ini sebagai berikut:

H1: keahlian komite audit berpengaruh negatif signifikan terhadap manajemen laba. 


\section{Frekuensi Pertemuan rapat komite audit}

Frekuensi pertemuan rapat komite audit mengindikasikan dalam setahun berapa kali komite audit mengadakan pertemuan. Menurut LK Bapepam minimal adalah 4 kali dalam setahun. Selain hal itu Bapepam (2004) mensyaratkan bahwa komite audit mengadakan rapat sekurang-kurangnya sama dengan ketentuan minimal rapat dewan komisaris yang di tetapkan dalam Anggaran Dasar.Apabila semakin sering komite audit mengadakan frekuensi rapat maka akan semakin intens dalam membahas kegiatan perusahaan dan laporan keuangan, sehingga akan berdampak pada semakin menurunnya manajemen laba.

Penelitian yang di lakukan oleh Putri dan Laksito (2011) Hasil dari pengujian terhadap variabel jumlah pertemuan komite audit terhadap manajemen laba menunjukkan hubungan yang negatif namun tidak signifikan.Penelitian yang dilakukan oleh Almeida et.al. (2009) menyatakan bahwa frekuensi pertemuan rapat komite audit berpengaruh negatif terhadap Manajemen Laba. Hal ini juga di dukung penelitian Waweru dan Riro (2013) yang menyimpulkan bahwa frekuensi pertemuan rapat komite audit berpengaruh negatif terhadap manajemen laba. Penelitian lain yang dilakukan oleh Xie et.al (2003) menyatakan bahwa frekuensi pertemuan rapat komite audit berpengaruh negatif terhadap manajemen laba.Dengan demikian hipotesisnya adalah:

\section{H2: frekuensi pertemuan rapat komite audit berpengaruh negatif signifikan terhadap manajemen laba.}

\section{Ukuran Komite Audit}

Ukuran komite audit menunjukkan berapa jumlah komite audit yang dimiliki sebuah perusahaan. Apabila semakin banyak jumlah atau ukuran komite audit yang dimiliki oleh sebuah perusahaan berarti menunjukkan kinerja semakin baik sehingga akan semakin menurunkan indikasi terjadinya manajemen laba.

Lin,2006 dalam Prastiti(2013) berhasil membuktikan bahwa terdapat hubungan negatif antara antara ukuran komite audit dengan manajemen laba (discretionary accrual). Hasil tersebut mengindikasikan bahwa semakin besar ukuran komite audit maka kualitas pelaporan keuangan semakin terjamin. Sehingga besarnya ukuran komite audit dapat meminimalisasi terjadinya manajemen laba. Dengan demikian hipotesisnya adalah:

H3: Ukuran komite audit berpengaruh negatif signifikan terhadap manajemen laba.

\section{Keahlian Dewan Komisaris}

Fungsi dewan komisaris sebagai pengawas dan penasihat namun tidak bertindak sebagai pengambilan keputusan operasional karena tugas pengambilan keputusan operasional menjadi tanggung jawab direksi.Dewan komisaris diharapkan memiliki latar belakang akutansi dan keuangan agar efektivitas fungsi pengawasan dapat ditingkatkan (Prastiti, 2013).

Komisaris dapat mewakili kepentingan para pemegang saham dan terkadang memilki pengetahuan yang dalam atas kinerja keuangan mengingat fungsi dewan komisaris adalah bertanggung jawab atas kinerja perusahaan kepada para pemegang saham.Oleh karena itu keahlian dewan komisaris dalam bidang akutansi dapat meningkatkan kejelasan informasi yang dapat di percaya kepada pemegang saham bahwa laporan keuangan yang di berikan oleh manajemen sesuai dengan kenyataan sebenarnya.

Penelitian yang dilakukan oleh Prastiti dan Merianto (2013) menyatakan bahwa keahlian dewan komisaris berpengaruh terhadap manajemen laba. Hal ini juga didukung oleh penelitian Utami dan Rahmawati (2008) Artinya semakin ahli dewan komisaris 
mengindikasikan kinerja yang semakin baik dan akan berpengaruh terhadap indikasi menurunnya manajemen laba.Dengan demikian hipotesisnya adalah:

\section{H4: keahlian dewan komisaris berpengaruh negatif signifikan terhadap manajemen laba.}

\section{Komposisi Dewan Komisaris}

Komposisi dewan komisaris menunjukkan apakah dalam sebuah perusahaan memiliki komisaris independen atau tidak. Apabila sebuah perusahaan memiliki komisaris independen berarti akan semakin ketat evaluasinya sehingga akan semakin menurunkan indikasi terjadinya manajemen laba.

Penelitian Utami dan Rahmawati (2008) yang menyimpulkan komposisi dewan komisaris berpengaruh negatif signifikan terhadap manajemen laba. Sefiana (2009) yang menyimpulkan bahwa komposisi dewan komisaris berpengaruh negatif signifikan terhadap manajemen laba. Dengan demikian hipotesisnya adalah:

\section{H5: komposisi dewan komisaris berpengaruh negatif signifikan terhadap manajemen laba.}

\section{Ukuran Perusahaan}

Ukuran perusahaan menunjukkan apakah sebuah perusahaan memiliki total aset besar atau tidak. Apabila sebuah perusahaan memiliki ukuran perusahaan besar berarti menunjukkan kinerja makin baik sehingga akan semakin menurunkan indikasi terjadinya manajemen laba.

Semakin besar ukuran perusahaan ,biasanya informasi yang tersedia untuk investor dalam pengambilan keputusan sehubungan dengan investasi dalam perusahaan tersebut semakin banyak. Siregar dan Utama (2005).

Berdasarkan hasil penjelasan tersebut dan hasil penelitian-penelitian sebelum nya dengan hasil penelitian yang dilakukan oleh Jao dan Pagalung (2011) menyatakan bahwa ukuran perusahaan berpengaruh negatif terhadap manajemen laba.Sedangkan penelitian Gurai dan Herawati (2010) yang menyimpulkan ukuran perusahaan berpengaruh positif signifikan terhadap manajemen laba.Hal sama di jelaskan oleh penelitian Wawero dan Riro (2009) yang menyimpulkan bahwa ukuran perusahaan berpengaruh positif signifikan terhadap manajemen laba. Dengan demikian hipotesisnya adalah:

H6: ukuran perusahaan berpengaruh signifikan terhadap manajemen laba.

\section{Leverage}

Leverage menunjukkan seberapa besar utang yang dimiliki oleh sebuah perusahaan. Apabila sebuah perusahaan memiliki utang yang tinggi berarti menunjukkan kinerja tidak baik sehingga akan semakin meningkatkan indikasi terjadinya manajemen laba. Semakin tinggi leverage menunjukkan risiko yang semakin tinggi karena risiko yang diterimanya akan semakin tinggi tetapi return yang diperoleh juga semakin tinggi pula.Hal ini akan berdampak pada kemungkinan manajemen melakukan manajemen laba lebih tinggi pula.

Penelitian Gurai dan Herawati (2010) yang menyimpulkan leverage berpengaruh positif signifikan terhadap manajemen laba.Wawero dan Riro (2009) yang menyimpulkan bahwa leverage berpengaruh positif signifikan terhadap manajemen laba. Dengan demikian hipotesisnya adalah:

H7: Leverage berpengaruh positif signifikan terhadap manajemen laba. 


\section{Reputasi Auditor}

Reputasi auditor menunjukkan seberapa baik reputasi auditor dalam hal ini adalah pengelompokan auditor perusahaan termasuk dalam kategori Big four atau non Big four. Apabila sebuah perusahaan diaudit oleh KAP Big four berarti menunjukkan kinerja semakin baik sehingga akan semakin menurunkan indikasi terjadinya manajemen laba.

Perusahaan yang diaudit oleh auditor yang berkualitas akan cenderung meningkatkan kepercayaan masyarakat terhadap laporan keuangan perusahaan karena mereka mempercayai kualitas auditor sebab dalam melakukan audit mereka lebih hati-hati dalam mendeteksi kecurangan dalam salah saji laporan keuangan yang di hasilkan.

Penelitian Widyaningsih (2011) yang menyimpulkan reputasi auditor berpengaruh negatif signifikan terhadap manajemen laba. Nabila dan Daljono (2013) yang menyimpulkan bahwa reputasi auditor berpengaruh negatif signifikan terhadap manajemen laba. Dengan demikian hipotesisnya adalah:

H8: Reputasi auditor berpengaruh negatif signifikan terhadap manajemen laba.

\section{METODE PENELITIAN}

\section{Populasi dan Sampel}

Populasi adalah seperangkat unit yang menjadi perhatian peneliti (Butar Butar, 2007). Populasi yang dimaksud dalam penelitian ini adalah semua perusahaan yang terdaftar di Bursa Efek Indonesia. Sampel dalam penelitian ini ditentukan berdasarkan metode purposive sampling, yaitu metode pengambilan sample yang didasarkan pada kriteriakriteria tertentu yang telah ditetapkan. Kriteria tersebut adalah : 1) Perusahaan yang terdaftar di BEI yang mempublikasikan laporan keuangan untuk tahun 2009-2013. 2) Perusahaan yang datanya tersedia secara lengkap. 3) Tersedia data untuk komite audit dan komisaris independen, jumlah pertemuan rapat komite audit, keahlian dewan komisaris.

Tabel 1. Kriteria Pengambilan Sampel

\begin{tabular}{|l|r|r|r|r|r|r|}
\hline Kriteria Pengambilan Sampel & $\mathbf{2 0 0 9}$ & $\mathbf{2 0 1 0}$ & $\mathbf{2 0 1 1}$ & $\mathbf{2 0 1 2}$ & $\mathbf{2 0 1 3}$ & Total \\
\hline $\begin{array}{l}\text { Jumlah perusahaan yang terdaftar } \\
\text { di BEI }\end{array}$ & 319 & 323 & 329 & 338 & 356 & 1655 \\
\hline $\begin{array}{l}\text { Perusahaan yang datanya tidak } \\
\text { tersedia }\end{array}$ & $(61)$ & $(56)$ & $(57)$ & $(59)$ & $(56)$ & $(289)$ \\
$\begin{array}{l}\text { Perusahaan yang datanya tidak } \\
\text { lengkap untuk: }\end{array}$ & $(13)$ & $(11)$ & $(12)$ & $(0)$ & $(0)$ & $(36)$ \\
$\begin{array}{l}\text { a. Komisaris independen } \\
\text { b. Jumlah pertemuan rapat } \\
\text { komite audit }\end{array}$ & $(50)$ & $(52)$ & $(48)$ & $(42)$ & $(38)$ & $(230)$ \\
$\quad$ c. Keahlian dewan komisaris & $(28)$ & $(25)$ & $(28)$ & $(22)$ & $(16)$ & $(119)$ \\
\hline
\end{tabular}




\begin{tabular}{|l|r|r|r|r|r|c|}
\hline Jumlah sampel perusahaan & 179 & 194 & 212 & 229 & 240 & 991 \\
\hline
\end{tabular}

Berdasarkan pada tabel1 diatas diketahui bahwa dari 1655 observasi dari 5 tahun dan setelah disaring sesuai dengan kriteria diperoleh sampel akhir 991 sampel selama 5 tahun.

Data yang digunakan dalam penelitian ini adalah data sekunder, yaitu dari sumber lain yang sudah dipublikasikan, seperti laporan keuangan perusahaan serta Indonesia Capital Market Directory tahun 2009-2013.

\section{Pengukuran Variabel}

Variabel dependen dari penelitian ini adalah Manajemen Laba yang diukur dengan menggunakan Discretionary Accruals (DA). Mengukur Total Accruals dengan menggunakan metode Jones yang dimodifikasi. Alasan digunakannya metode Jones yang dimodifikasi adalah karena model ini dianggap paling baik diantara model yang lain untuk mengukur manajemen laba. Pada model jones tidak memasukkan Piutang (RECEIVABLE) sedangkan pada model jones modified telah memasukkan unsur tersebut sehingga hasilnya lebih baik dan akurat untuk mengukur manajemen laba Dechow et al(1995) dalam Utami dan Rahmawati(2008). Proses penghitungan discretionary accrual dilakukan melalui beberapa tahap. Pertama dilakukan pengukuran total accruals $\left(\mathrm{TA}_{\mathrm{it}}\right)$, yaitu:

$$
\text { Total accruals }(\mathrm{TAC})=\text { laba bersih }- \text { arus kas operasi }
$$

Setelah itu menghitung nilai total accruals diestimasi dengan persamaan regresi:

$$
T A C_{i t} / T A_{i, t-1}=\alpha_{1}\left(\mathrm{TA}_{i, t-1}\right)+\beta_{1}\left(\Delta S A L_{i t} / T A_{i, t-1}\right)+\beta_{2}\left(P P E_{i t} / T A_{i, t-1}\right)+\varepsilon_{i t}
$$

Penghitungan terlebih dahulu dilakukan dengan regresi linear berganda terhadap $\mathrm{TAC}_{\mathrm{it}} / \mathrm{TA}_{\mathrm{it}-1}$ sebagai variabel dependen serta $\Delta \mathrm{SAL}_{\mathrm{it}} / \mathrm{TA}_{\mathrm{it}-1}$ dan $\mathrm{PPE}_{\mathrm{it}} / \mathrm{TA}_{\mathrm{it}-1}$ sebagai variabel independennya. Dengan melakukan regresi terhadap ketiga variabel tersebut, maka akan diperoleh koefisien dari variabel independen, yaitu $\alpha_{1}=-0,001, \beta_{1}=-0,028$, $\beta_{2}=0,062$ yang akan dimasukkan ke persamaan berikut ini:

$$
D A_{i t}=T A C_{i t} / T A_{i, t-1}-a 1\left(T A_{i, t-1}\right)+\beta 1\left[\left(\Delta S A L_{i t}-\Delta R E C_{i t}\right) / T A_{i, t-1}\right]+\beta 2\left(P P E_{i t} / T A_{i, t-1}\right)
$$

Keahlian komite audit diukur dengan prosentase komite audit yang berpendidikan akutansi dan atau keuangan dengan total atau jumlah anggota komite audit. Frekuensi pertemuan komite audit dihitung dari frekuensi pertemuan rapat komite audit diukur dengan berapa kali komite audit mengadakan rapat dalam setahun. Ukuran komite audit dihitung dari jumlah komite audit yang dimliki perusahaan. Keahlian dewan komisaris diukur dengan prosentase perbandingan antara dewan komisaris yang memiliki keahlian di bidang akutansi atau keuangan dengan total dewan komisaris. Komposisi dewan komisaris dihitung dari jumlah komisaris independen dengan total dewan komisaris perusahaan. Ukuran perusahaan diukur dengan logaritma total aset perusahaan. Leverage menggunakan rasio yang didapat dari perhitungan total kewajiban dibagi total aset. Reputasi auditor diukur dengan 
variabel dummy yaitu 1 jika diaudit oleh KAP yang berafiliasi dengan KAP Big four dan 0 jika diaudit oleh KAP yang tidak berafiliasi dengan KAP Non Big four. Kantor akuntan publik yang termasuk dalam big four antara lain: (1) Deloitte Touche Tohmatsu, (2)PriceWaterhouse Coopers, (3) Ernst and Young, (4)KPMG.

\section{Model Penelitian}

Model yang digunakan untuk menguji hipotesis pada penelitian ini adalah:

$$
\begin{aligned}
\text { Abs_dacc }= & b_{0}+b_{1} K \_ \text {Audit }+b_{2} \text { Frek_KA }+b_{3} U k \_K A+b_{4} K \_D K+b_{5} \text { Ind_DK }+ \\
& b_{6} \operatorname{Size}+b_{7} \text { DER }+b_{8} \text { Rep_Aud }+e
\end{aligned}
$$

Notasi :

$\begin{array}{ll}\text { Abs_dacc } & =\mid \text { discretionary accruals } \mid \\ \text { Ke_KA } & =\text { keahlian komite audit (persentase komite audit } \\ & \text { berpendidikan akuntansi dengan total komite audit) } \\ \text { Frek_KA } & \text { frekuensi pertemuan rapat komite audit (jumlah rapat } \\ & \text { dalam setahun) } \\ & =\text { keahlian dewan komisaris (persentase dewan } \\ \text { Ke_DK } & \text { komisaris berpendidikan akuntansi dengan total dewan } \\ & \text { komisaris) } \\ & =\text { komposisi dewan komisaris (persentase komisaris } \\ \text { D_Ind } & \text { independen dengan total dewan komisaris) } \\ \text { Uk_Pe } & =\text { ukuran perusahaan (log. Total aset) } \\ \text { LEV } & =\text { leverage (DER) } \\ \text { Rep_Aud } & =\text { reputasi auditor (dummy variabel) } \\ \text { Uk_KA } & =\text { ukuran komite audit (jumlah komite audit) } \\ \text { e } & =\text { error }\end{array}$

\section{ANALISIS DAN PEMBAHASAN}

Statistik Deskriptif

Pada bagian ini akan dibahas mengenai statistik deskriptif pada penelitian ini. Dari data awal berjumlah 991 observasi, ternyata ada cukup banyak data yang tidak normal sehingga data normalnya berjumlah 840 observasi untuk mengestimasi akrual diskresioner pada normalitas manajemen laba. Kemudian dilanjutkan uji normalitas data untuk pengujian hipotesis dan data normalnya menjadi 550.

Tabel 3.2. Statistik Deskriptif

\begin{tabular}{|l|l|l|l|l|l|}
\hline & N & Minimum & Maximum & Mean & Std. Deviation \\
\hline K_Audit & 550 & 0,00 & 1,00 & 0,33 & 0,21 \\
Frek_KA & 550 & 1,00 & 52,00 & 6,76 & 6,43 \\
Uk_Ka & 550 & 2,00 & 7,00 & 3,04 & 0,32 \\
K_DK & 550 & 0,00 & 1,00 & 0,34 & 0,22 \\
Ind_DK & 550 & 0,03 & 0,67 & 0,35 & 0,11 \\
Size & 550 & 10,06 & 14,83 & 12,34 & 1,02 \\
DER & 550 & 0,00 & 1,97 & 0,49 & 0,27 \\
Abs_dacc & 550 & 0,04 & 0,16 & 0,05 & 0,04 \\
& & & & & \\
\hline
\end{tabular}


Berdasarkan pada tabel 3.2 di atas dapat diketahui bahwa variabel akrual absolut (Abs_dacc) memiliki nilai minimum akrual sebesar 0,04 dan nilai maksimum sebesar 0,16 sedangkan nilai rata-rata sebesar 0,05 serta standar deviasi 0,04 yang artinya ratarata perusahaan pada penelitian ini melakukan manajemen laba sebesar 5\% dari total asset perusahaan.

Sedangkan untuk keahlian komite audit (K_Audit) memiliki nilai minimum keahlian komite audit 0 dan nilai maksimal keahlian komite audit 1 sedangkan nilai rata-rata sebesar 0,33 . Artinya komite audit perusahaan yang berpendidikan atau berpengalaman di bidang akuntansi sebesar 33\% dari total komite audit perusahaan.

Frekuensi rapat komite audit (Frek_KA) memiliki nilai minimum 1 dan nilai maksimum 52 sedangkan nilai mean atau rata-rata sebesar 6,76 dengan standar deviasi 6,43. Artinya rata-rata frekuensi rapat komite audit dalam setahun rata-rata sebesar 6-7 kali.

Untuk ukuran komite audit (Uk_KA) memiliki nilai minimum 2 dan nilai maksimum 7 sedangkan rata-ratanya 3,04. Artinya jumlah komite audit perusahaan ratarata 3 orang dan ini sesuai dengan peraturan dari BAPEPAM. Sesuai dengan Surat Edaran dari Direksi PT. Bursa Efek Jakarta No.SE-008/BEJ/12-2001, jumlah anggota komite audit sekurang-kurangnya 3 (tiga) orang. Adanya ukuran komite audit yang tepat dapat memaksimalkan pengalaman dan keefektifan mereka dalam bekerja untuk memberikan hasil yang terbaik dalam pengawasan laporan keuangan khususnya bagi pihak stakeholder.

Sedangkan untuk variabel Keahlian Dewan Komisaris (K_DK) perusahaan sampel memiliki nilai minimum 0 dan nilai maksimal 1 sedangkan nilai rata-rata sebesar 0,34 artinya perusahaan memiliki keahlian dewan komisaris yang berpendidikan akuntansi dan keuangan dibandingkan total dewan komisaris sebesar 34\% dengan standar deviasi 0,11 .

Variabel Independensi Dewan Komisaris (Ind_DK) memiliki nilai minimum 0,03 dan nilai maksimal 0,67 sedangkan nilai rata-rata $0, \overline{3} 5$ yang artinya rata-rata prosentase komposisi dewan komisaris independen dibandingkan total dewan komisaris 35\%

Size Perusahaan memiliki nilai minimum 10,06 dan nilai maksimal 14,83. Sedangkan nilai memiliki rata-rata sebesar 12,34.

Untuk variabel Leverage (DER) nilai minimum 0 dan nilai maksimum 1,97 yang menunjukkan bahwa nilai maksimum perusahaan memiliki hutang sebesar 1,97 dibandingkan dengan jumlah modal yang di miliki. Sedangkan nilai rata-rata sebesar 0,49 menunjukkan bahwa rata-rata perusahaan memiliki hutang 0,49 kali dari total modal yang dimiliki. Rasio besarnya DER yang tinggi, mengindikasikan bahwa perusahaan memiliki risiko yang tinggi untuk mengalami kebangkrutan, sehubungan dengan tingginya kewajiban yang harus dipenuhi. Nilai ini menunjukkan bahwa risiko yang dialami perusahaan normal dan tidak terlalu tinggi.

Tabel 3.3. Frekuensi Reputasi Auditor

\begin{tabular}{|c|c|c|c|c|}
\hline & Frequency & Percent & Valid Percent & $\begin{array}{c}\text { Cumulative } \\
\text { Percent }\end{array}$ \\
\hline 0.00 & 324 & 59.1 & 58.9 & 58.9 \\
1.00 & 226 & 40.9 & 41.1 & 100.0 \\
Total & 550 & 100.0 & 100.0 & \\
\hline
\end{tabular}


Rep_Aud atau reputasi auditor menunjukkan ada 326 perusahaan atau 58,9\% yang diaudit oleh KAP Non Big Four. Sedangkan 226 perusahaan atau 41,1\% sisanya diaudit oleh KAP Big Four.

\section{Hasil Pengujian Normalitas Akrual Diskresioner}

Untuk pengujian normalitas data pada penelitian ini dilakukan dengan menggunakan uji Kolmogorov Sminov dan Shapiro Wilk. Data awal sebanyak 991 data memiliki data yang tidak normal. Maka perlu dilakukan penghilangan data tidak normal. Observasi akhir menjadi 840.

\section{Pengujian Hipotesis}

\section{Hipotesis Pertama}

Hipotesis pertama memprediksi keahlian komite audit berpengaruh negatif signifikan terhadap manajemen laba. Dari tabel 4.11. diketahui nilai signifikansi t untuk variabel Keahlian Komite Audit adalah sebesar $0,000<0,05$ tetapi nilai koefisien regresi +0.029 sehingga artinya hipotesis pertama pada penelitian ini tidak diterima.

Komite audit yang berfungsi optimal diharapkan mampu mengurangi upaya perusahaan untuk melakukan manajemen laba dan memastikan direksi bertindak dengan mementingkan kepentingan pemegang saham. Elemen komite audit yang diperiksa adalah ukuran komite audit,keahlian keuangan komite audit, frekuensi kegiatan komite audit, tingkat kehadiran rata-rata komite audit dalam kegiatan yang melibatkan mereka.

Dari tabel 4.11 menunjukkan keahlian komite audit dalam sebuah perusahaan tidak berdampak pada manajemen laba. Hal ini disebabkan dilihat dari statistik deskriptif penelitian untuk variabel keahlian komite audit memperoleh nilai rata-rata sebesar 34\% yang mana menunjukkan kurang dari separuh dari total anggota komite audit yang berpendidikan akuntansi keuangan sehingga tidak cukup baik dalam mengontrol terjadinya manajemen laba dan ini menjadikan hipotesis ditolak sehingga keahlian komite audit tidak berpengaruh terhadap manajemen laba.

Selain hal itu komite audit yang bertugas membantu dewan komisaris hanya mempunyai keterbasan dalam menjalankan fungsi, kewajiban dan hak mereka sehingga tanggung jawab komite audit terhadap dewan komisaris untuk membantu mereka dalam mengawasi Direksi dan Dewan Manajemen serta memastikan penerapan prinsip-prinsip tata kelola perusahaan yang baik, menjadi terbatas.

Hal tersebut disebabkan oleh adanya kenyataan bahwa pembentukan komite audit yang mempunyai keahlian di bidang akutansi dan keuangan hanya di dasarkan pada peraturan yang berlaku, sesuai Bapepam tentang komite audit bahwa perusahaan wajib memiliki setidaknya tiga orang yang salah satunya mempunyai keahlian akutansi atau keuangan sehingga kurang berfungsi mengoptimalkan kompetensi mereka dalam mendeteksi manajemen laba yang ada pada perusahaan.Hasil penelitian ini konsisten dengan penelitian Putri dan Laksito (2010) juga Prastiti dan Meiranto (2013).

\section{Hipotesis Dua}

Hipotesis dua memprediksi frekuensi pertemuan rapat komite audit berpengaruh negatif signifikan terhadap manajemen laba. Dari tabel 4.11. diketahui nilai signifikansi t untuk variabel Frekuensi rapat Komite Audit adalah sebesar 0,0075< 0,05 sehingga hipotesis kedua pada penelitian ini diterima. Jadi Frekuensi rapat Komite Audit berpengaruh negatif signifikan terhadap manajemen laba. 
Frekuensi pertemuan rapat komite audit mengindikasikan dalam setahun berapa kali komite audit mengadakan pertemuan. Menurut LK Bapepam minimal adalah 4 kali dalam setahun. Selain hal itu Bapepam (2004) mensyaratkan bahwa komite audit mengadakan rapat sekurang-kurangnya sama dengan ketentuan minimal rapat dewan komisaris yang di tetapkan dalam Anggaran Dasar. Apabila semakin sering komite audit mengadakan frekuensi rapat maka akan semakin intens dalam membahas kegiatan perusahaan dan laporan keuangan, sehingga akan berdampak pada semakin menurunnya manajemen laba. Hasil penelitian ini konsisten dengan penelitian Carcello et al (2010).

\section{Hipotesis Tiga}

Hipotesis tiga memprediksi bahwa ukuran komite audit berpengaruh negatif terhadap manajemen laba. Dari tabel 4.11. diketahui nilai signifikansi t untuk variabel ukuran komite audit adalah sebesar $0,030<0,05$ dan nilai koefisien regresi -0.014 sehingga artinya hipotesis pada penelitian ini diterima. Jadi Ukuran komite audit berpengaruh negatif signifikan terhadap manajemen laba.

Ukuran komite audit menunjukkan berapa jumlah komite audit yang dimiliki sebuah perusahaan. Apabila semakin banyak jumlah atau ukuran komite audit yang dimiliki oleh sebuah perusahaan berarti menunjukkan kinerja semakin baik sehingga akan semakin menurunkan indikasi terjadinya manajemen laba.

Mengingat fungsi komite audit melakukan pengawasan dan keterbukaan pelaporan keuangan yang berkualitas keberadaan komite audit dapat meningkatkan keefektifan dalam menurunkan indikasi terjadinya manajemen laba.Hasil penelitian ini mendukung penelitian yang dilakukan oleh Putri dan Laksito (2010).

\section{Hipotesis Empat}

Hipotesis keempat memprediksi keahlian dewan komisaris berpengaruh negatif signifikan terhadap manajemen laba. Dari tabel 4.11. diketahui nilai signifikansi t untuk variabel Keahlian Dewan Komisaris adalah sebesar

$0,030<0,05$ dan nilai koefisien regresi -0.014 sehingga artinya hipotesis pada penelitian dapat diterima. Jadi Keahlian dewan komisaris berpengaruh negatif terhadap manajemen laba.

Keahlian dewan komisaris mengindikasikan apakah dewan komisaris dalam sebuah perusahaan berpendidikan akutansi atau tidak. Keahlian dewan komisaris dalam pendidikan akutansi memiliki pengetahuan yang cukup luas untuk mendeteksi masalah masalah dalam laporan keuangan, selain itu komite komite yang di buat oleh dewan komisaris akan di bentuk sesuai pengalaman yang ada pada keahlian dewan komisaris yang mana pengetahuan dewan komisaris di bidang akutansi dapat membantu memilih komite yang bekerja di bawah perintah nya dapat kompeten dalam menjalan kan tugasnya.

Hal itu di karenakan dewan komisaris mewakili kepentingan para pemegang saham atas kinerja keuangan perusahaan sehingga dewan komisaris yang mempunyai keahlian dapat mendeteksi terjadinya manajemen laba yang terjadi.

\section{Hipotesis Lima}

Hipotesis kelima memprediksi komposisi dewan komisaris independen berpengaruh negatif signifikan terhadap manajemen laba. Dari tabel 4.11. diketahui nilai signifikansi $t$ untuk variabel D_Ind adalah sebesar $0,0025<0,05$ dan tetapi nilai koefisien regresi +0.06 sehingga artinya hipotesis kelima pada penelitian ini tidak diterima. 
Hal ini disebabkan karena dewan komisaris independen kurang dari optimal dalam mengawasi manajemen dalam suatu perusahaan. Perusahaan tercatat wajib memiliki komisaris independen yang jumlahnya proposional sebanding dengan jumlah saham yang dimiliki oleh bukan pemegang saham pengendali dengan ketentuan jumlah komisaris independen sekurang-kurangnya $30 \%$ dari jumlah seluruh anggota komisaris. Jika di lihat dari hasil statistik deskriptif ketentuan dewan komisaris yang minimum belum cukup tinggi untuk mendominasi kebijakan yang di ambil dewan komisaris sehingga kurang optimal dalam menjalankan monitoring terhadap perusahaan. Komposisi dewan komisaris yang tinggi diharapkan mampu lebih optimal untuk fungsi dalam pengawasan manjemen laba dalam perusahaan, Selain itu besar kecilnya dewan komisaris bukanlah menjadi faktor penentu utama dari efektivitas pengawasan terhadap manajemen perusahaan. Akan tetapi efektivitas mekanisme pengendalian tergantung pada nilai, norma dan kepercayaan yang diterima dalam suatu organisasi serta peran dewan komisaris dalam aktivitas pengendalian (monitoring) terhadap manajemen.

Proporsi dewan komisaris independen tidak berpengaruh untuk mengurangi manajemen laba pada perusahaan. Hal ini dapat dijelaskan bahwa pengangkatan dewan komisaris independen oleh perusahaan mungkin hanya dilakukan untuk pemenuhan regulasi saja untuk menghindari sanksi terhadap perusahaan yang tidak memenuhi peraturan yang berlaku. Hasil penelitian ini konsisten yang di lakukan oleh Siregar dan Utama(2005) dan Guna dan Herawaty (2006).

\section{Hipotesis Enam}

Hipotesis keenam memprediksi ukuran perusahaan berpengaruh terhadap manajemen laba. Dari tabel 4.11. diketahui ternyata nilai signifikansi t untuk variabel Uk_Pe adalah sebesar $0,000<0,05$ sehingga artinya hipotesis keenam pada penelitian diterima.

Arah yang positif dengan nilai koefisien regresi $+0,006$ menunjukkan ukuran perusahaan dapat mempengaruhi manajemen laba dimana perusahaan besar memiliki aktivitas operasional yang lebih kompleks sehingga memungkinkan dilakukannya manajemen laba. Ukuran perusahaan yang besar cenderung mempunyai laba yang tinggi sehingga banyak investor untuk menanamkan modal kepada perusahaan tersebut, selain itu semua pelaporan keuangan dan manajemen di ketahui oleh publik maka perusahaan besar melakukan tindakan manajemen laba untuk menjaga image mereka. Perusahaan besar cenderung mempertahankan laba yang tinggi untuk mendapatkan modal dan kepercayaan masyarakat bahwa perusahaan bisa memberikan jaminan dana yang di hasilkan untuk di jadikan investasi .

Disamping itu, perusahaan besar harus mampu memenuhi ekspektasi dari investor dan banyak estimasi serta penilaian yang harus diterapkan pada perusahaan besar. Dengan demikian, ukuran perusahaan dapat dijadikan sebagai pertimbangan bagi calon investor untuk melakukan investasi dan pengambilan keputusan, di sisi lain perusahaan kecil juga mempunyai pengaruh terhadap manajemen laba hal ini di karenakan perusahaan kecil yang mempunyai daya saing untuk berkembang sehingga mempertahankan laba agar bisa bertahan dalam melangsungkan usaha nya agar dapat lebih baik untuk kesejahteraan perusahaan pada tahun - tahun yang akan datang, sehingga ukuran perusahan mempunyai pengaruh terhadap manajemen laba pada perusahaan.Hasil penelitian tidak konsisten dengan penelitian yang dilakukan oleh Jao dan Pagalung (2011). 


\section{Hipotesis Tujuh}

Hipotesis ketujuh memprediksi leverage berpengaruh positif signifikan terhadap manajemen laba. Dari tabel 4.11. diketahui ternyata nilai signifikansi t untuk variabel LEV adalah sebesar 0,404 > 0,05 dengan koefisien regresi $+1,04$ sehingga artinya hipotesis pada penelitian ditolak. Jadi LEV tidak berpengaruh signifikan terhadap manajemen laba.

Perusahaan dengan tingkat leverage yang tinggi akibat besarnya total hutang terhadap total modal akan menghadapi resiko default yang tinggi yaitu perusahaan terancam tidak mampu memenuhi kewajibannya. Perusahaan akan berusaha menghindarinya dengan membuat kebijaksanaan yang dapat meningkatkan pendapatan maupun laba. Hasil penelitian ini tidak sesuai dengan debt convenant hypothesis yang menyatakan bahwa semakin dekat perusahaan terhadap pelanggaran perjanjian utang berbasis akuntansi, semakin mungkin manajer memilih prosedur akuntansi yang menggeser laba dari periode yang akan datang ke periode sekarang dan sebaliknya. Bila perusahaan memiliki rasio utang/ekuitas lebih tinggi, para manajer lebih cenderung menggunakan metode akuntansi yang meningkatkan pendapatan. Semakin tinggi rasio utang/ekuitas, perusahaan semakin dekat dengan kendala dalam perjanjian utang. Pelanggaran perjanjian mengakibatkan biaya standar teknis sehingga untuk itu manajemen laba dilakukan.

Leverage yang aman dalam arti perusahaan mampu membayar hutang yang digunakan untuk membiayai aset perusahaan, maka manajer tidak tertarik atau tidak termotivasi untuk melakukan praktek manajemen laba. Ini disebabkan karena perusahaan tidak membutuhkan tindakan-tindakan yang akan membantu perusahaan dalam situasi tertentu. Perusahaan berada pada keadaan yang baik atau aman dan mampu untuk membayar hutang yang digunakan untuk membiayai aset perusahaan sehingga perusahaan tidak melakukan manajemen laba. Hal ini menjadikan leverage tidak berpengaruh terhadap manajemen laba.

Hasil penelitian ini didukung oleh hasil penelitian yang dilakukan Jao dan Panggalung (2011) yang menyatakan leverage tidak mempunyai pengaruh signifikan terhadap manajemen laba pada perusahaan manufaktur yang terdaftar di Bursa Efek Indonesia. Hal ini berarti jika leverage perusahaan mengalami peningkatan, maka tingkat manajemen laba yang dilakukan akan tetap atau konstan.

\section{Hipotesis Delapan}

Hipotesis kedelapan memprediksi reputasi auditor berpengaruh negatif signifikan terhadap manajemen laba. Dari tabel 4.11. diketahui ternyata nilai signifikansi t untuk variabel Rep_Aud adalah sebesar $0,167>0,05$ sehingga artinya hipotesis pada penelitian ini tidak diterima. Jadi Rep_Aud tidak berpengaruh signifikan terhadap manajemen laba.

bahwa KAP Big Four ternyata belum mampu membatasi praktik manajemen laba. Kualitas audit yang diproksikan dengan ukuran KAP, dalam penelitian ini tidak berpengaruh terhadap manajemen laba. Hal ini dimungkinkan praktik manajemen laba terjadi karena perusahaan memiliki keinginan agar kinerja keuangan perusahaan tampak bagus dimata calon investor.

Selain itu alasan hasil kualitas auditor di pengaruhi oleh integritas auditor sehingga tidak menutup kemungkinan terjadinya kecurangan meskipun di audit oleh KAP Big Four. Hasil dari statistik deskritif menunjukan sebagian besar perusahaan di audit oleh KAP Non Big Four sehingga menunjukkan tidak ada pengaruh terhadap pendeteksian manajemen laba.Hasil penelitian ini konsisten dengan yang di lakukan oleh Nabila dan Daljono (2013). 


\section{SIMPULAN}

\section{Kesimpulan}

Berdasarkan pada hasil analisis data pada bagian sebelumnya maka dapat ditarik kesimpulan sebagai berikut:

1. Terdapat pengaruh positif signifikan antara Keahlian Komite audit terhadap manajemen laba.

2. Frekuensi Rapat komite audit berpengaruh negatif signifikan terhadap manajemen laba.

3. Ukuran Komite Audit berpengaruh negatif signifikan terhadap manajemen laba.

4. Keahlian Dewan Komisaris berpengaruh negatif signifikan terhadap manajemen laba.

5. Komposisi Dewan Komisaris berpengaruh positif signifikan terhadap manajemen laba.

6. Size (Ukuran Perusahaan) berpengaruh signifikan terhadap manajemen laba.

7. DER (Leverage) tidak berpengaruh signifikan terhadap manajemen laba.

8. Reputasi Auditor tidak berpengaruh signifikan terhadap manajemen laba.

\section{Saran}

Sedangkan saran yang dapat dikemukakan pada penelitian ini antara lain adalah:

1. Sebaiknya pihak perusahaan dan investor dapat memperhatikan Keahlian Komite audit, Frekuensi Rapat komite audit, Ukuran komite audit, Komposisi Dewan komisaris Independen dan Ukuran perusahaan karena berdasarkan pada penelitian ini terbukti secara empiris terhadap manajemen laba.

2. Pada penelitian dengan topik serupa dimasa mendatang dapat ditambahkan variabel lain yang mempengaruhi manajemen laba, misalnya rasio profitabilitas, aktivitas, CSR. 


\section{DAFTAR PUSTAKA}

Bryan, D., Liu, M. H. C., dan Tiras, S. L,. January 2004. The Influence of Independent and Effective Audit Committees on Earnings Quality", Working Papers.

Butar Butar, S. 2007. Modul Statistik dan Aplikasi SPSS. Semarang: Fakultas Ekonomi Unika Soegijapranata.

Butar Butar, S. 2012. Peluang Riset Akuntansi Berbasis Akrual Di Indonesia. Jurnal Online Universitas Udayana 7: 1-12.

Butar Butar, S. 2014. Implikasi Regulasi Pasar Modal Terhadap Motif Manajemen Laba: Pengujian Berbasis Teori Pensinyalan. Jurnal Akuntansi Keuangan Indonesia 11 (1): 99-119

Butar Butar, S. 2016. Merger Auditor dan Kualitas Audit: Bukti Empiris Dari Bursa Efek Indonesia. Jurnal Ekonomi dan Bisnis 17 (2): 107-128

Carcello, J. V. dan Neal, T. L,. Oktober 2000. Audit Committee Compositian and Auditor Reporting. The Accounting Review, 75 (4).

Carolina dan Januarti, 2005. Analisis Faktor-Faktor yang Berpengaruh terhadap Perataan Laba (Income Smoothing) pada Perusahaan-Perusahaan Go Public. Jurnal Akuntansi dan Keuangan 7 (2):148-161.

Choi, S dan Jeter, C.D. 1990. The Effect of Qualifield Audit Opinions on Earnings Response Coefficients. Journal of Accounting and Economics 15, hal 229-247.

Fidyati. 2004. Pengaruh Corporate Governance terhadap Earning Management pada Perusahaan SEO. Jurnal Ekonomi dan Akuntansi 2 (1).

Gurai dan Herawati. 2010. Pengaruh Mekanisme Corporate Governance, Independensi Auditor, Kualitas Audit dan Faktor Lainnya terhadap Manajemen Laba. Jurnal Bisnis dan Akuntansi 12 (1).

Halim, J., C. Meiden dan R. L. Lumban Tobing. 2005. Pengaruh Manajemen Laba pada Tingkat Pengungkapan Laboran Keuangan pada Perusahan Manufaktur yang Termasuk dalam Indeks LQ-45. Simposium Nasional Akuntansi (SNA) VII. Solo.

Jensen, M. and W. Meckling. 1976. Theory of the Firm: Managerial Behavior, Agency, and Ownership Structure. Journal of Financial Economics 3 (2): 305-360.

Klien, A. 2002. Audit Committee, Board of Director Caracteristics and Earnings Managemen. Journal Accounting and Economics 33: 375-400.

Meutia. 2004. Pengaruh independensi auditor terhadap manajemen laba untuk. KAP big 5 dan non big 5. Jurnal riset akuntansi indonesia 7(3). 
Midiastuty, P., dan M. Machfoedz. 2003. Analisis Hubungan Mekanisme Corporate Governance dan Indikasi Manajemen Laba. Simposium Nasional Akuntansi (SNA) VI, Surabaya.

Prastiti, A dan W. Meiranto. 2013. Pengaruh Karakteristik Dewan Komisaris Dan Komite Audit Terhadap Manajemen Laba. Diponegoro Journal Of Accounting 2 (4).

Putri, D.M., dan H. Laksito. 2011. Pengaruh Karakteristik Komite Audit Terhadap Manajemen Laba (Studi Empiris pada Perusahaan Manufaktur yang Terdaftar di Bursa Efek Indonesia Periode Tahun 2007-2009). Skripsi. Universitas Diponegoro.

Saldo dan Z. Baridwan. 2000. Peran dan Fungsi Komisaris Independen dan Komite Audit. Makalah seminar Konvensi Nasional Akuntansi IV. 6-7 September Jakarta.

Scott, W. R. 2000. Financial Accounting Theory. International Edition. New Jersey: Prentice Hall, Inc.

Sefiana, E. 2009. Pengaruh Penerapan Corporate Governance Terhadap Manajemen Laba Pada Perusahaan Perbankan Yang Telah Go Public Di BEI. Skripsi. Jurusan Akuntansi Fakultas Ekonomi, Universitas Gunadarma.

Siregar dan Utama. 2005. Pengaruh Struktur Kepemilikan, Ukuran Perusahaan, dan Praktik Corporate Governance terhadap Pengelolaan Laba (Earnings Management). SNA VIII, Solo.

Utami dan Rahmawati. 2008. Pengaruh Komposisi Dewan Komisaris dan Keberadaan Komite Audit terhadap aktivitas Manajemen Laba pada perusahaan manufaktur yang terdaftar di Bursa Efek Jakarta. SKEN Veteran, Yogyakarta.

Wedari, L. K. 2004. Analisis Pengaruh Proporsi Dewan Komisaris dan Keberadan Komite Audit terhadap Aktivitas Manajemen Laba. Simposium Nasional Akuntansi (SNA) VI, IAI, Denpasar.

Widyaningdyah, A. U. 2001. Analisis Faktor-Faktor yang Berpengaruh terhadap Earnings Management Pada Perusahaan Go Public di Indonesia. Jurnal Akuntansi dan Keuangan 3 (2): 89-101.

Xie, B., W. N Davidson III., dan P. Dadalt. 2003. Earnings Management and Corporate Governance: The Role of Board and the Audit Committee. Journal of Corporate Finance. 9 (3): 295-316. 